\title{
Penambahan Abu Ampas Tebu (AAT) dan Limbah Boma Bisma Indra (BBI) untuk Pembuatan Paving Block
}

\author{
FX Didik Harijanto, Endang Kasiati, Boedi Wibowo, Sulchan Arifin \\ Program Studi Diploma Teknik Sipil FTSP ITS, Surabaya \\ Email: didihari2@yahoo.com
}

\begin{abstract}
During the manufacturing process PT Boma Bisma Indra (BBI) produces unused-waste material, in the form of silica sand. As fine aggregate additives in the mix paving block, Silica sand has the advantages of its small porosity, high in density, hardness, and water-tightness and containing $\mathrm{SiO}_{2}$ compounds that are silica reactive. In this research, fine aggregate of concrete block paving is mixed of BBI waste silica sand and sand with the ratio to the weight of sand of $0 \%, 5 \%, 10 \%$, $15 \%$, and $20 \%$. The concrete block paving is made by mixture of 1 PC: 1 sand (and waste material): 2 course aggregate: 2 fly ash with $10 \%$ by weight of cement of additional material AAT. Course aggregate used has size of $5 \mathrm{~mm}$. The concrete block paving has dimension of $21 \mathrm{~cm}$ long, $10.5 \mathrm{~cm}$ wide, and $6 \mathrm{~cm}$ thick. Compressive strength test at the age of 7, 14, 21, 28 days and diffusion at 28 days. From the test results the highest strength is $589.51 \mathrm{~kg} / \mathrm{cm}^{2}$. It is the mixture of $10 \%$ the waste material and $10 \%$ AAT. It meets compressive strength standard of SNI 03-06911996, i.e., A quality. Optimal diffusion as large as $3.12 \%$ is obtained with the mix of the $20 \%$ ratio of waste material to sand and $10 \%$ AAT. It meets the standard diffusion with quality of $B$.
\end{abstract}

Keywords: Paving block, BBI Waste, Compressive Strength, Diffusion, AAT.

Abstrak

Pada proses pembuatan besi cor PT Boma Bisma Indra (BBI) ada limbah buangan yang tidak terpakai, berupa pasir silika. Pasir silika ini sebagai bahan tambahan agregat halus dalam campuran paving block yang mempunyai keunggulan yaitu porositasnya kecil, kepadatan, kekerasan, kekedapannya tinggi, dan banyak mengandung senyawa $\mathrm{SiO}_{2}$ yang bersifat sebagai silika reaktif. Pada penelitian ini pembuatan paving block dilakukan dengan cara menambah sebagian pasir dengan limbah BBI yaitu dengan variasi; $0 \%, 5 \%, 10 \%, 15 \%$, dan $20 \%$ dari berat pasir ke masing-masing campuran 1 PC : 1 Pasir : 2 Stenslag : 2 Abu Batu dengan bahan tambahan AAT 10\% yang diambil dari berat semen. Stenslag yang digunakan mempunyai ukuran $5 \mathrm{~mm}$. Pembuatan paving block dengan ukuran $P=21 \mathrm{~cm}, L=10,5 \mathrm{~cm}$, dan $T=6 \mathrm{~cm}$. Uji kuat tekan dilakukan pada umur 7, 14, 21 dan 28 hari dan resapan pada umur 28 hari. Dari hasil pengujian didapatkan hasil tertinggi pada variasi penambahan limbah $10 \%$ dan AAT $10 \%$ dengan kuat tekan sebesar $589,51 \mathrm{~kg} / \mathrm{cm}^{2}$ yang telah memenuhi standar kuat tekan SNI 03-0691-1996, yakni mutu $A$ dan resapan yang optimum pada variasi penambahan limbah $20 \%$ dan AAT $10 \%$ sebesar $3,12 \%$, telah memenuhi standar resapan, yakni mutu $B$.

Kata kunci: Paving block, Limbah BBI, Kuat tekan, Resapan, AAT.

\section{Pendahuluan}

Dengan semakin berkembangnya jaman penggunaan paving block semakin dibutuhkan dan digunakan sebagai jalan komplek-komplek perumahan, taman, tempat rekreasi, jalan-jalan setapak dan lain sebagainya. Paving block dengan bahan dasar agregat yang ditambah material pengikat sangat baik digunakan sebagai perkerasan tanah. Agregat yang dimaksud dalam pembuatan paving block adalah pasir, abu batu, stenslag dengan sedikit penambahan abu ampas tebu dan pasir silika dari limbah BBI sebagai bahan tambahan pasir.

Setiap harinya PT BBI membuang limbah 3-5 ton yang menyebabkan pencemaran lingkungan, maka dari itu dilakukan penelitian dengan maksud dapat memanfaatkan limbah BBI ini sebagai

Jurnal APLIKASI: Media Informasi \& Komunikasi Aplikasi Teknik Sipil Terkini Halaman 17 
bahan yang dapat berguna untuk mengurangi pembuangan limbah yang semakin menumpuk, kandungan limbah BBI ini hampir mirip dengan copper slag yang pernah diteliti sebelumnya sebagai cementtious material terhadap kuat tekan mortar dengan menggunakan metode perawatan uap dengan kuat tekan rata-rata sebesar $1261,88 \mathrm{~kg} / \mathrm{cm}^{2}$ sedangkan yang mengalami kenaikan tanpa menggunakan cooperslag sebesar $1242,79 \mathrm{~kg} / \mathrm{cm}^{2}$ (M. Nurdiansyah '06). Adapun bahan - bahan yang dipakai adalah sbb:

- Semen Gresik Type I

- Pasir Mojokerto

- Stenslag ukuran $5 \mathrm{~mm}$

- Abu batu

-Abu Ampas Tebu (AAT)

Tabel 1. Mutu paving block

\begin{tabular}{cccc}
\hline \multirow{2}{*}{ Mutu } & \multicolumn{2}{c}{$\begin{array}{c}\text { Kuat Tekan } \\
(\text { Mpa })\end{array}$} & $\begin{array}{c}\text { Penyerapan Air } \\
\text { Rata-rata } \\
\end{array}$ \\
\cline { 2 - 3 } & Rata-Rata & Min. & $(\%)$ \\
\hline A & 40 & 35 & 3 \\
B & 20 & 17 & 6 \\
C & 15 & 12,5 & 8 \\
D & 10 & 8,5 & 10 \\
\hline
\end{tabular}

\subsection{Limbah Pasir Silika BBI}

Bahan pengganti agregat halus yang digunakan dalam penelitian ini adalah sejenis slag dari industri baja tuang PT Boma Bisma Indra yang memproduksi mesin-mesin industri dan komponenkomponen pelengkapnya. Proses produksi menggunakan metode pengecoran, yaitu meleburkan bahan pembuatan baja ditambah dengan bahan pendukung lain. Limbah pasir silika BBI berasal dari sisa moulding atau campuran bahan adonan cor yang tidak melebur. Dalam satu kali pengecoran, limbah yang dihasilkan sebanyak 5\%-8\% dari berat campuran atau 3-5 Ton per hari. Banyaknya limbah yang dihasilkan dipengaruhi oleh kesempurnaan dalam pelaksanaan pembakaran. Semakin baik pembakarannya atau dalam suhu tinggi dan stabil, maka limbah yang dihasilkan semakin sedikit dan sebaliknya. Pasir silika sendiri berasal dari Desa Jenuh Kabupaten Tuban, dalam penelitian ini penulis mengambil bahan baku limbah pasir silika dari sisa hasil produksi baja tuang yaitu PT Boma Bisma Indra yang berada di Pasuruan.

Dalam pemanfaatan limbah BBI dalam campuran paving block, dicoba mengkombinasikan limbah pasir silika ini dengan agregat halus. Adapun senyawa kimia pada limbah BBI seperti Tabel 2 (Hasil Analisa Balai Penelitian Pengembangan Industri).

Tabel 2. Senyawa kimia pada limbah BBI

\begin{tabular}{ccc}
\hline 1 & $\mathrm{SiO}_{2}$ & $43,30 \%$ \\
2 & $\mathrm{Al}_{2} \mathrm{O}_{3}$ & $30,50 \%$ \\
3 & $\mathrm{CaO}$ & $2,01 \%$ \\
4 & $\mathrm{MgO}$ & $1,31 \%$ \\
5 & $\mathrm{Fe}_{2} \mathrm{O}_{3}$ & $48,90 \%$ \\
6 & $\mathrm{~K}_{2} \mathrm{O}-\mathrm{Na}_{2} \mathrm{O}$ & $0,34 \%$ \\
7 & $\mathrm{SO}_{3}$ & $1,05 \%$ \\
\hline
\end{tabular}

Didalam material limbah pasir silika terdapat unsur $\mathrm{SiO}_{2}$ yang bersifat sebagai silika reaktif, sehingga hal ini sangat menguntungkan bagi tercapainya reaksi terhadap semen dan pada akhirnya akan menambah kekuatan beton atau paving block.

Pada proses hidrasi semen yang menghasilkan senyawa CSH yang bersifat sebagai pengikat juga menghasilkan kapur $\mathrm{Ca}(\mathrm{OH})_{2}$ yang bersifat merugi-

Halaman 18 Jurnal APLIKASI: Media Informasi \& Komunikasi Aplikasi Teknik Sipil Terkini 
kan, dengan adanya silika aktif dalam limbah pasir silika maka kapur yang timbul akan bereaksi kembali membentuk pengikat baru yaitu CSH.

Dimana kalsium silikat hidrat (CSH) sangat berperan dalam pengerasan semen. Reaksi kalsium hidroksida $\mathrm{Ca}(\mathrm{OH})_{2}$ ini berasal dari reaksi antara semen dan air, dimana kalsium hidroksida apabila berada pada lingkungan yang agresif akan menimbulkan korosi pada mortar maupun beton sehingga dapat mengurangi kuat tekannya. Dengan adanya $\mathrm{SiO}_{2}$ peranan kalsium hidroksida $\mathrm{Ca}(\mathrm{OH})_{2}$ dapat diperkecil (Nurdiansyah, 2006).

\subsection{Pasir}

Penggunaan pasir sebagai bahan agregat halus untuk membuat campuran mortar atau paving block harus dipilih dengan kualifikasi yang baik atau memenuhi gradasi pasir sesuai BS 882 atau ASTM C 136 dan harus bebas bahan organik, lempung, atau bahan-bahan yang dapat merusak campuran mortar atau paving yang sesuai standar ASTM C 33 (Standard Specification for concrate Agregates).

Pasir yang digunakan untuk pembuatan paving dalam penelitian ini menggunakan bahan agregat halus atau pasir alami yang diambil dari daerah Mojokerto. Hal ini dikarenakan pada pasir Mojokerto, kadar lumpurnya dan bahan organis yang terkandung dalam jumlah yang sedikit sehingga memenuhi kriteria yang disyaratkan.

\subsection{Gradasi Gabungan}

Apabila perencanaan campuran paving didasarkan pada gradasi dari agregat maka perlu untuk mempertimbangkan gradasi gabungan dari pasir Mojokerto dan limbah pasir silika limbah BBI, hal ini sangat penting karena susunan gradasi agregat tersebut akan menentukan sifat dari paving, yaitu kemudahan pekerjaan serta keekonomisan dari campuran paving.

\subsection{Abu Batu}

Abu batu merupakan sampingan dari produksi batu pecah. Abu batu merupakan jenis tertentu campuran batubatuan atau abu gunung berapi yang mengandung banyak silika, alumina dan mengandung senyawa alkali, besi, kapur dan sebagainya walaupun dalam kadar yang rendah. Abu batu berbentuk seperti kerikil tetapi mempunyai diameter lebih kecil yaitu kurang dari $5 \mathrm{~mm}$.

Dari setiap daerah, komposisi abu batu digunakan dalam aduk beton terutama untuk memperbaiki sifat dari beton. Pemakaian abu batu dapat menghemat pemakaian semen. Abu batu mengandung senyawa silika yang sangat halus yang bersifat amorf sehingga mampu mengeras bila dicampur dengan semen. Senyawa yang terjadi antara silika amorf dan kapur adalah senyawa Silikat Kalsium yang sukar larut dalam air. Kemampuan pengersan dari abu batu karena adanya bagian-bagian silika amorf yang halus (Fauzi, 2006).

\subsection{Abu Ampas Tebu}

Abu ampas tebu (AAT) adalah limbah padat hasil sisa pembuangan pabrik gula Tulangan yang berupa ampas tebu yang

Jurnal APLIKASI: Media Informasi \& Komunikasi Aplikasi Teknik Sipil Terkini Halaman 19 
melalui proses pembakaran dan diambil abunya kemudian diambil sampel untuk diteliti kadar silikat tertinggi, sebelumnya sample AAT ini dioven tujuannya untuk mengeringkan dan menghilangkan kadar organik yang mungkin terkandung didalamnya. Pengovenan sampel dilakukan di laboratorium Teknik Kimia ITS.

Abu Ampas Tebu termasuk dalam golongan pozzolan buatan yang sebenarnya banyak macamnya, baik merupakan sisa pembakaran dari tungku, maupun hasil pemanfaatan limbah yang diolah menjadi abu dan mengandung silika reaktif dengan melalui proses pembakaran, seperti abu terbang (fly ash), abu sekam, silika fume, abu ampas tebu dan lain-lain. AAT yang telah dioven selanjutnya diteliti kandungan $\mathrm{SiO}_{2}, \mathrm{Al}_{2} \mathrm{O}_{3}, \quad \mathrm{Fe}_{2} \mathrm{O}_{3}, \mathrm{Na}_{2} \mathrm{O}_{3}$, dan $\mathrm{SO}_{3}$ penelitian ini dilakukan di Balai Penelitian dan Konsultasi Industri Laboratorium Penelitian dan Konsultasi Industri, Surabaya. Dalam penelitian ini AAT diarahkan sebagai bahan penambah dari semen hal ini dikarenakan bahwa AAT mempunyai sifat fisik seperti pozolan dan mengandung silika reaktif (Rangga, 2005).

\section{Metodologi}

\subsection{Pengadaan Material}

Sebelum pembuatan campuran benda uji paving block dibuat, terlebih dahulu disiapkan material yang digunakan dan sesuai tujuan pembuatan paving block tersebut.

Material yang digunakan adalah:

- Semen Gresik tipe I
- Pasir Mojokerto

- Limbah Pasir BBI

- Abu Batu

- Stenslag

- Air PDAM

- Abu Ampas Tebu

Tabel 3. Sifat Kimia AAT

\begin{tabular}{cc}
\hline Uraian & Hasil Uji (\%) \\
\hline Silika dioksida, $\mathrm{SiO}_{2}$ & 72,33 \\
Besi (III) dioksida, $\mathrm{Fe}_{2} \mathrm{O}_{3}$ & 0,85 \\
Alumuninm oksida, $\mathrm{Al}_{2} \mathrm{O}_{3}$ & 3,24 \\
Calsium & 0,63 \\
Magnesium & 0,58 \\
Carbon & 10,91 \\
Kadar Air & 3,79 \\
\hline Sumber: Departemen Perindustrian Badan Penelitian dan \\
Pengembangan Industri
\end{tabular}

\subsection{Analisa Bahan}

Pengujian yang dilakukan adalah sebagai berikut:

- Berat Jenis

- Analisa Ayakan

- Resapan Air

- Kelembaban

- Kandungan bahan organik

\subsection{Perencanaan Komposisi Cam- puran}

Dalam penelitian ini, kami mencoba mencari komposisi antara PC, pasir, stenslag, abu batu dan abu ampas tebu sehingga menghasilkan paving block dengan efektifitas dan kualitas yang maksimum. Setelah itu dilakukan percobaan untuk mengetahui hasil komposisi campuran yang telah direncanakan dan diklasifikasikan menurut mutu yang telah disyaratkan dalam SNI 03-06911996.

Komposisi campuran yang telah direncanakan adalah sebagai berikut: 
1 PC : 1 Pasir: 2 Stenslag : 2 Abu Batu $+10 \%$ AAT, dengan penambahan pasir silika limbah BBI $0 \%, 5 \%, 10 \%, 15 \%$ dan $20 \%$ terhadap jumlah berat pasir Mojokerto (dapat dilihat pada Tabel 3).

\subsection{Pembuatan Benda Uji}

Benda uji paving block dibuat berdasarkan SNI-03-0691-1996. Pembuatan benda uji paving block dapat diproduksi baik secara mekanis maupun secara manual. Dalam penelitian ini digunakan secara mekanis. Proses pembuatan benda uji paving block adalah sebagai berikut:

a) Pencampuran bahan material dibuat sesuai komposisi yang telah direncanakan.

b) Bahan material yang sudah ditakar sesuai komposisi dimasukkan ke dalam mixer hingga menjadi homogen dan ditambahkan dengan air.

c) Campuran dimasukkan ke dalam mesin pencetak paving "Multi Block" dengan ukuran paving 21 $\mathrm{cm} \times 10,5 \mathrm{~cm} \times 6 \mathrm{~cm}$.

d) Campuran di dalam cetakan diratakan menggunakan papan yang rata kemudian dipress untuk memadatkan bahan dan digetarkan selama \pm 3 detik.

e) Paving block hasil cetakan diangkat dari cetakan kemudian dianginanginkan.

\subsection{Perawatan Benda Uji}

Untuk memberikan hasil yang baik, diperlukan penyimpanan dan perawatan terhadap benda uji yang telah dicetak. Tujuan perawatan adalah mencegah pengeringan yang bisa menyebabkan kehilangan air yang dibutuhkan untuk proses pengerasan sehingga kebutuhan air selama proses hidrasi semen tidak berkurang. Perawatan untuk paving block dilakukan setelah paving block dicetak yaitu diletakkan di tempat penyimpanan sementara selama dua puluh empat jam, setelah itu perawatan benda uji dilakukan dengan cara menyirami paving block dimulai sejak sehari setelah pencetakan selama 2 hari lalu diangin-anginkan hingga kemudian diuji kuat tekan paving block.

Tabel 3. Paving block (1 benda uji)

\begin{tabular}{cccccccc}
\hline No & $\begin{array}{c}\text { Komposisi Campuran } \\
(1 \text { 1PC:1Ps:2AB:2Stn })\end{array}$ & $\begin{array}{c}\text { PC } \\
\text { (gr) }\end{array}$ & $\begin{array}{c}\text { Pasir } \\
\text { (gr) }\end{array}$ & $\begin{array}{c}10 \% \text { AAT } \\
\text { (gr) }\end{array}$ & $\begin{array}{c}\text { Limbah BBI } \\
\text { (gr) }\end{array}$ & $\begin{array}{c}\text { Abu Batu } \\
\text { (gr) }\end{array}$ & $\begin{array}{c}\text { Stenslag } \\
\text { (gr) }\end{array}$ \\
\hline 1 & $0 \%$ & 674,7 & 586,5 & 67,47 & 0 & 1181,9 & 1159,8 \\
2 & $5 \%$ & 674,7 & 586,5 & 67,47 & 29,32 & 1181,9 & 1159,8 \\
3 & $10 \%$ & 674,7 & 586,5 & 67,47 & 58,65 & 1181,9 & 1159,8 \\
4 & $15 \%$ & 674,7 & 586,5 & 67,47 & 87,97 & 1181,9 & 1159,8 \\
5 & $20 \%$ & 674,7 & 586,5 & 67,47 & 117,3 & 1181,9 & 1159,8 \\
\hline
\end{tabular}

Jurnal APLIKASI: Media Informasi \& Komunikasi Aplikasi Teknik Sipil Terkini Halaman 21 

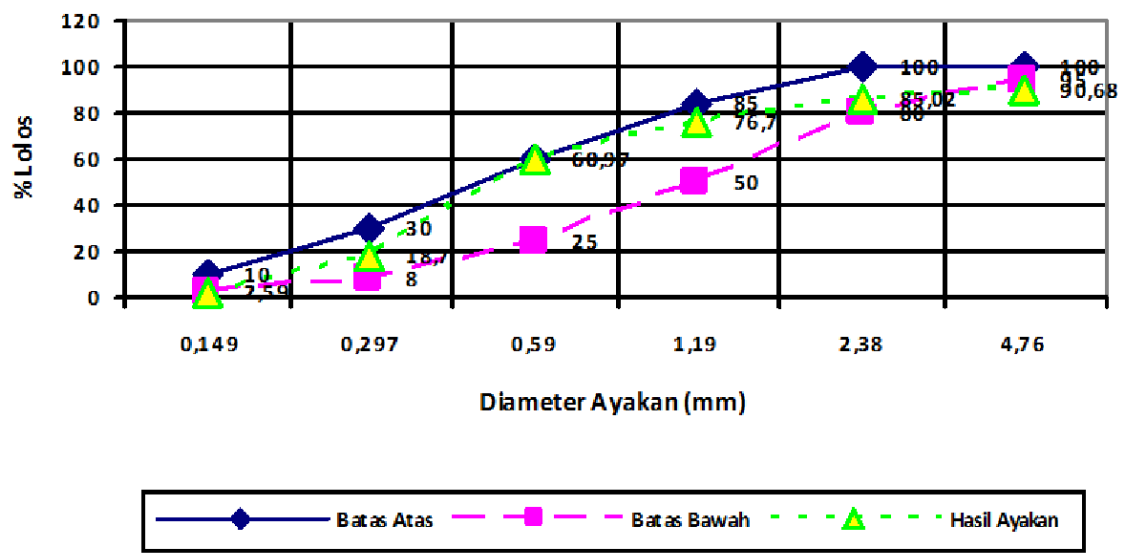

Gambar 1. Hasil analisa ayakan pasir alami di Zone 3

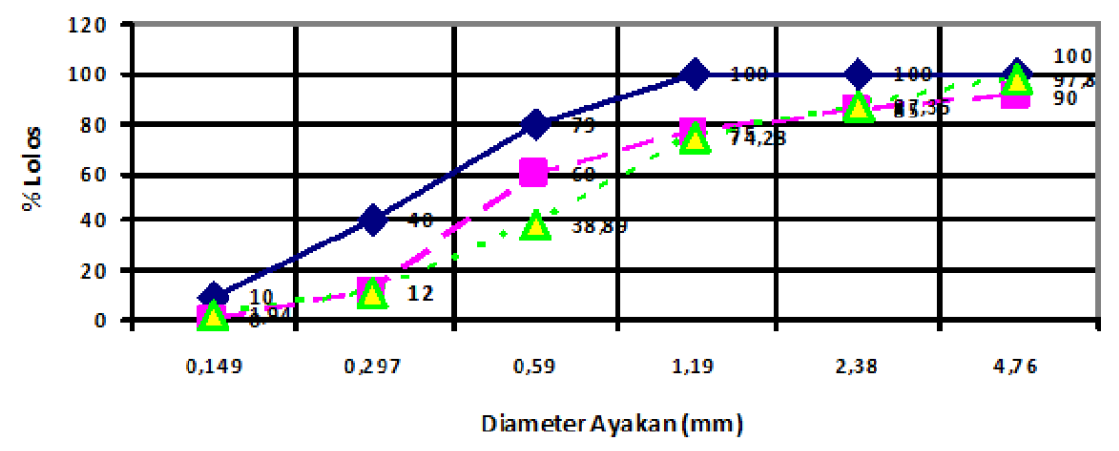

- Batas Atas - - - BatasBawah = - - -4 - ' Hasil Ayakan

Gambar 2. Hasil analisa ayakan pasir alami $+5 \%$ di Zone 2

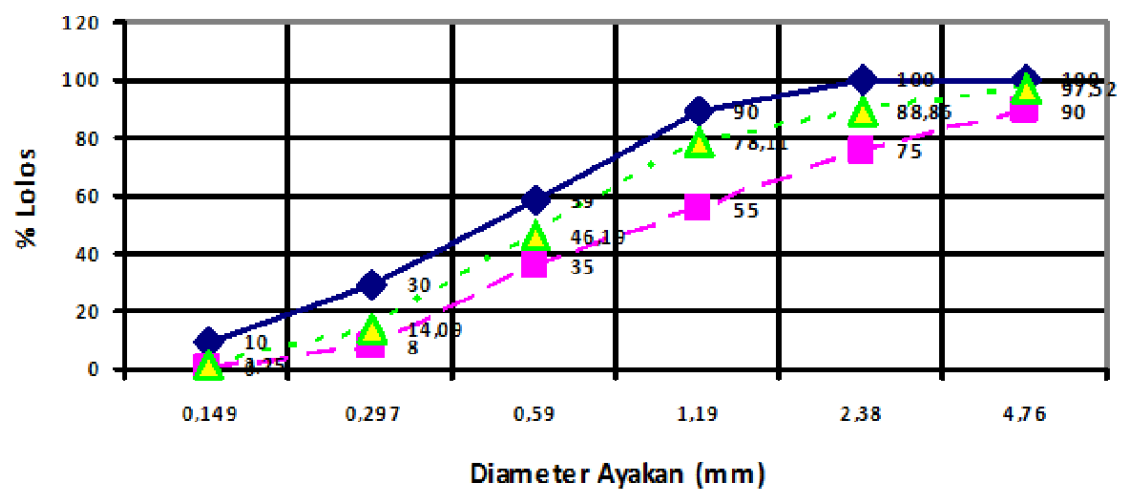

- Batas Atas - - - Batas Bawah " - "

Gambar 3. Hasil analisa ayakan pasir alami $+10 \%$ Silika di Zone 2

Halaman 22 Jurnal APLIKASI: Media Informasi \& Komunikasi Aplikasi Teknik Sipil Terkini

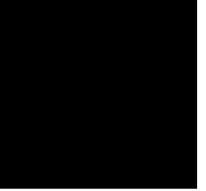




\section{ISSN.1907-753X}

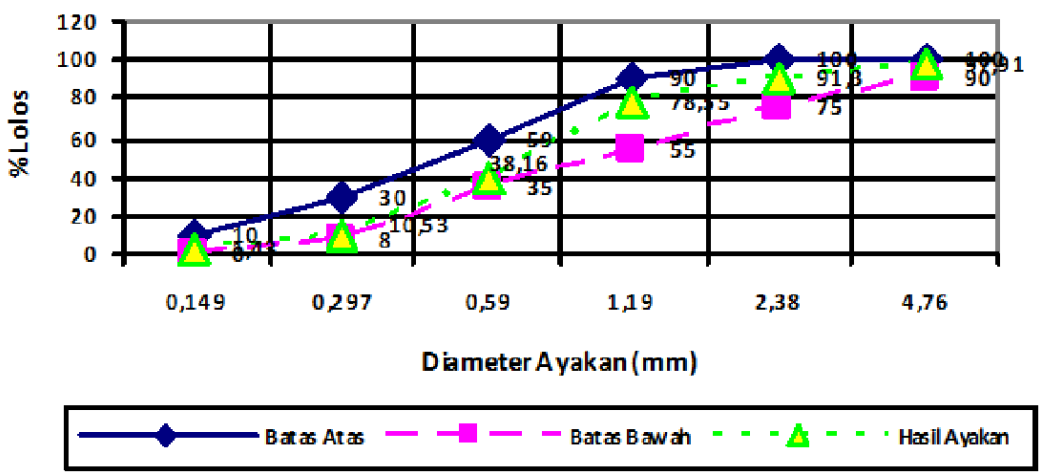

Gambar 4. Hasil analisa ayakan pasir alami $+15 \%$ Silika di Zone 2

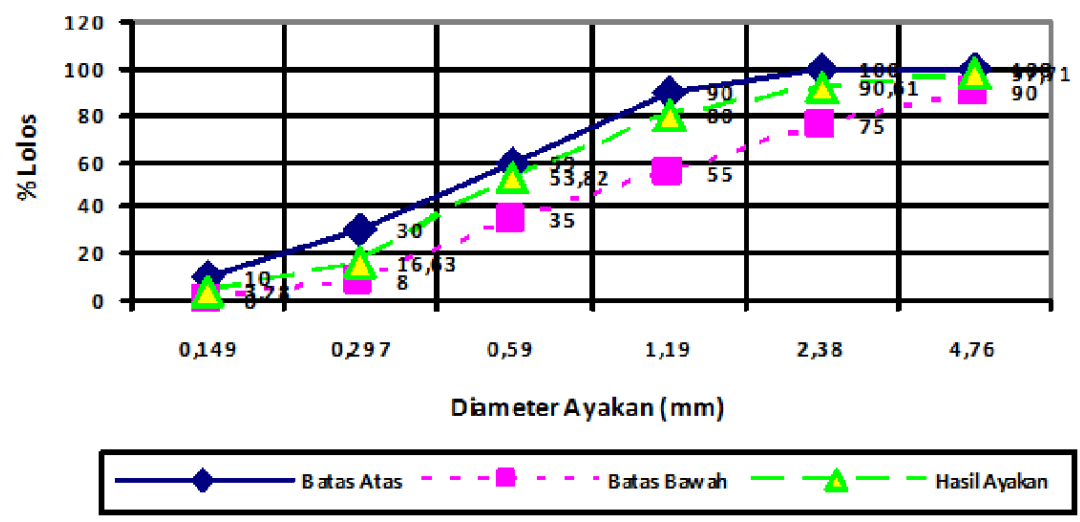

Gambar 5. Hasil analisa ayakan pasir alami $+20 \%$ Silika di Zone 2
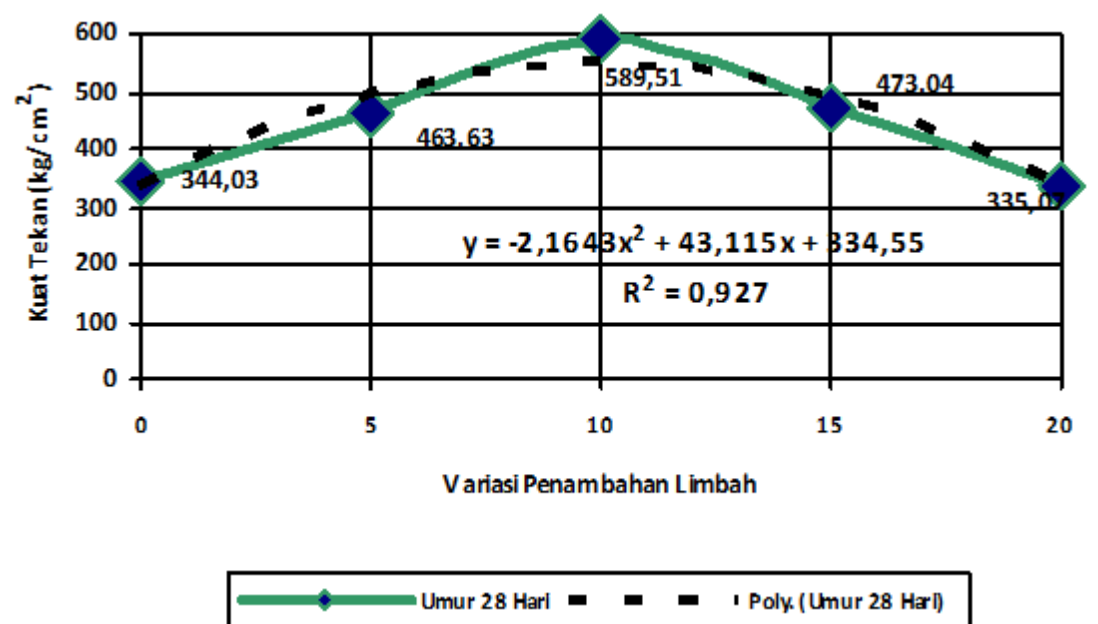

Gambar 6. Kuat tekan paving umur 28 hari di Zone 2 

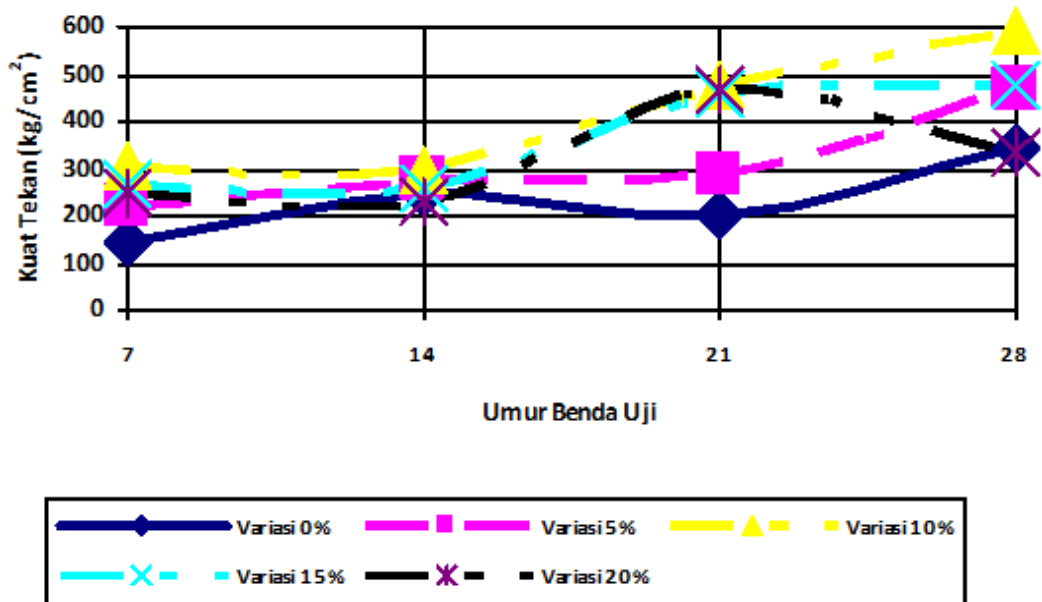

Gambar 7. Hubungan antara kuat tekan dan umur paving block di Zone 2
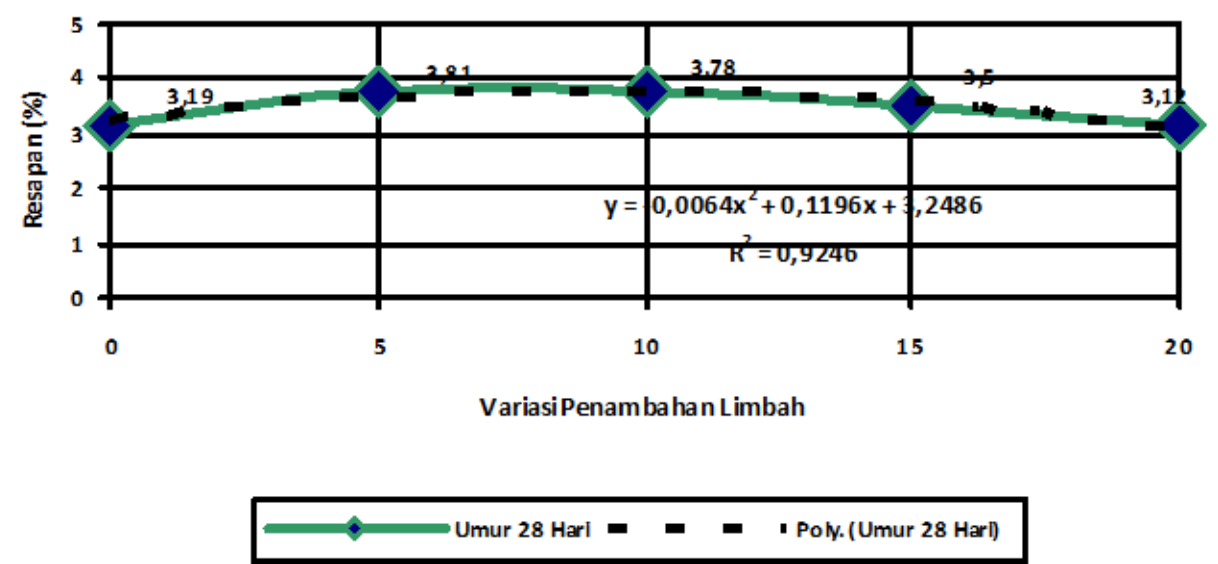

Gambar 8. Grafik resapan di Zone 2

\section{Hasil dan Pembahasan}

Tabel 4. Hasil Analisa Material Pasir Alami

\begin{tabular}{llc}
\hline No. & Analisa sifat fisik & Pasir Alami \\
\hline 1 & Berat Jenis & 2.66 \\
2 & Resapan & 5.62 \\
3 & Kelembaban & 4.74 \\
4 & Kadar Zat Organik & Baik \\
5 & Modulus Kehalusan & 2.65 \\
\hline
\end{tabular}

Dari hasil uji ayakan pasir alami seperti terlihat pada Tabel 4 dan Gambar 1-5, selanjutnya digambarkan pada grafik lengkung untuk ayakan pasir (Gambar 1). Klasifikasi pasir Mojokerto tersebut termasuk pada grading zone 3 yang mempunyai karakteristik halus, setelah dicampur 5\% dengan pasir silika masuk pada grading zone 2 yang mempunyai karakteristik kasar (Gambar 2), demikian pula sampai dengan penambahan pasir silika $20 \%$ masuk pada grading zone 2 yaitu mempunyai karakteristik kasar (Gambar 5).

Pengujian kuat tekan paving pada umur 28 hari relatif sudah sempurna. Dengan penambahan limbah BBI dan AAT kuat tekannya akan mengalami kenaikan yang cukup besar pada variasi limbah 
$10 \%$ umur 28 hari yaitu $71 \%$ dibandingkan paving tanpa limbah dengan kuat tekan mencapai $589,51 \mathrm{~kg} / \mathrm{cm}^{2}$ seperti pada Gambar 6. yang masuk dalam kualifikasi kuat tekan paving block mutu A. Kuat tekan yang tinggi dimungkinkan karena ikatan/lekatan antara semen dan agregat, sehingga pasta semen dapat menyelimuti semua agregat dan juga dipengaruhi adanya reaksi bahan tambahan AAT yang bersifat seperti pozzolan.

Pengujian resapan paving pada umur 28 hari yang optimum (rendah) pada variasi limbah $20 \%$ mencapai penurunan $2 \%$ dibandingkan paving tanpa limbah seperti pada Gambar 8. yang masuk dalam kualifikasi resapan paving block mutu B.

\section{Simpulan}

Dari hasil penelitian yang telah dilakukan serta analisa yang telah diuraikan dapat disimpulkan sebagai berikut:

1. Limbah pasir silika BBI dapat digunakan sebagai bahan penambah agregat halus dalam campuran pembuatan paving block, hal ini dapat dilihat dari hasil uji kuat tekan yang tinggi dari pada yang tidak menggunakan bahan tambahan (Limbah BBI).

2. Dengan penambahan limbah BBI $0 \%, 5 \%, 10 \%, 15 \%, 20 \%$ dan AAT $10 \%$ pada campuran $1 \mathrm{PC}: 1$ Pasir : 2 Abu Batu : 2 Stenslag, kuat tekan tertinggi pada variasi penambahan limbah BBI 10\% umur 28 hari sebesar $589.51 \mathrm{~kg} / \mathrm{cm}^{2}$ yang masuk dalam kualifikasi kuat tekan paving block mutu A.
3. Resapan minimal didapat dengan variasi penambahan Limbah BBI $20 \%$ sebesar $3,12 \%$ yang masuk dalam kualifikasi resapan paving block mutu B.

\section{Daftar Pustaka}

ASTM. 2003. Anual Book of ASTM Standards, Concrete and Aggregates, Philadelphia: ASTM 2003.

Astana D. Yulius. 2000. Pengaruh Kombinasi Copperslag dan Pasir Lumajang dalam Campuran Beton yang Mengandung Fly Ash terhadap Kuat Tekan dan Berat Volume, Surabaya: Teknik Sipil Universitas Pembangunan Nasional.

Didit T. Rangga. 2005. Pengaruh Penambahan Abu Ampas Tebu pada Campuran Beton terhadap Modulus Elastisitas Beton dengan Variasi Faktor Air Semen, Surabaya: Teknik Sipil Universitas Pembangunan Nasional.

Fauzi Aminul and F. Aditya. 2006. Evaluasi Komposisi Campuran Paving Block dengan Variasi Campuran Pasir, Abu Batu, Stenslag dan Fly Ash dari Limbah PLTU Paiton, Surabaya: ITS.

Handriati A., 2008. Pemanfaatan Limbah untuk Bahan Bangunan, Puslitbang Permukiman.

Modul Disemenasi C-1, Pemanfaatan Agregat Halus (Pasir) untuk Komponen Bahan Bangunan, Puslitbang Permukiman.

Nurdiansyah M., 2006. Pengaruh Limbah Industri Peleburan Tembaga (Copperslag) sebagai Cementitious Material terhadap Kuat Tekan Mortar dengan Perawatan Uap (Steam Curing), Surabaya: UPN.

Jurnal APLIKASI: Media Informasi \& Komunikasi Aplikasi Teknik Sipil Terkini Halaman 25 
SNI 03-0691-1996, Standar Mutu Bata Beton (Paving Block).

Subakti Aman. 1994. Teknologi Beton dalam Praktek, Surabaya: ITS.

Sufiyah. 2005. Efektifitas Kombinasi Cooperslag sebagai Cementitious terhadap Kuat Tekan pada Beton, Surabaya: UPN.

Yudi P., 2005. Pengaruh Kombinasi Cooperslag sebagai Cementitious terhadap Porositas pada Campuran Beton, Surabaya: UPN. 